\title{
All eyes on Alberta
}

Previously published at www.cmaj.ca

I t's been more than a year and a half since Alberta radically changed its health care system consolidating power previously held by regional boards into a single entity responsible for all health care decisions - but interested observers across Canada say it's still too early to judge if the move was a winner or a blunder.

"You hear bits and pieces of things that have happened, and people try to attribute them to system change, but it's premature," says Pamela Fralick, president and chief executive officer of the Canadian Healthcare Association. "Everyone is watching. They are a bit of a petri dish."

In May 2008, the Alberta government began a massive restructuring of its health care system. The province dissolved its regional health authority system, created 15 years ago to provide decision-making power to designated regions, creating in its place a "superboard" called Alberta Health Services.

"Alberta Health Services incorporates Alberta's nine previous regional health authorities, the Alberta Mental Health Board, the Alberta Cancer Board and the Alberta Alcohol and Drug Abuse Commission. The aim of the provincial governance board is to increase access to health services and ensure Albertans benefit from one seamless provincial health care system. Our goal is to create a high quality and innovative system that provides equitable access to health services," Michaleen Elabdi, a spokesperson for Alberta Health and Wellness, wrote in an email.

At the time of the change, former Alberta health and wellness minister Ron Liepert told media the move would streamline the health care system, saving money that could be invested in front-line services. He proposed that the long-term savings of having one chief executive officer instead of nine would be substantial. Critics countered by claiming the

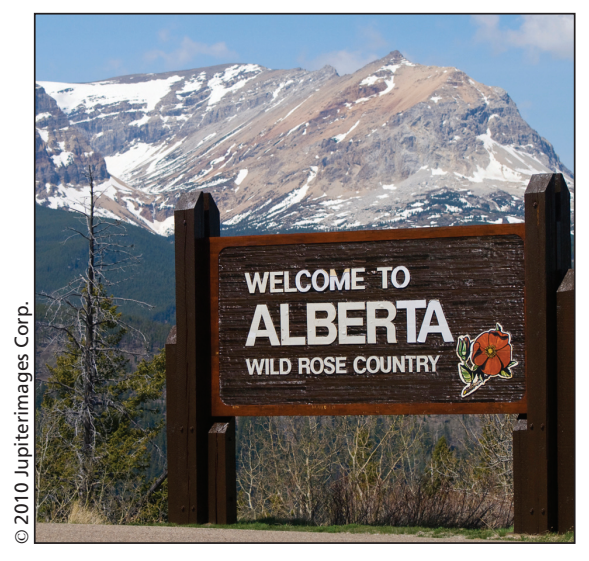

Alberta has long prided itself on its rugged individualism and it seems health care is no exception as the province boldly carved out a new path by abolishing regional health authorities. But critics say the move was intended to stifle political dissent, not to improve efficiency.

newly formed superboard was hardly lean and mean, but rather a Byzantine behemoth, with 90000 employees and 45 vice-presidents.

And critics of Alberta Health Services aren't hard to find. Some worry that its chief executive officer, Steven Duckett, has too much power. Others view the superboard as a club of out-oftouch bureaucrats who know little about the needs of Albertans, especially rural Albertans. "If I have a concern about health delivery or patient care, I would have previously gone to someone in my community," Dianne Wyntjes, regional director of the Alberta branch of the Canadian Union of Public Employees, which has adamantly opposed the new system from the start, wrote in an email. "Now what happens to my concern? Where does it go and who responds to me? How long does it take for me to get a response? How many Albertans know who actually sits on the Super board and knows about their background? What are the skills the Board members bring?"

Interested academics aren't so quick to claim that the abandoning of health regions was a mistake. Like Fralick, John
Church, an associate professor in the School of Public Health at the University of Alberta in Edmonton, says it's too early to tell if the creation of the superboard will prove beneficial or disastrous.

"I think people are watching the Alberta experiment very closely," he says. "If it works, I wouldn't be surprised to watch other provinces shift in a similar way, especially if it helps in controlling budgets.'

In 1998, Church wrote a paper in which he took a "critical perspective" of the regionalization of health care services in Canada (Int J Health Serv. 1998;28:467-86). He suggested that the proposed benefits of regionalization such as better coordination and integration of health care services, greater efficiency and responsiveness, provincewide equity of care, increased participation of citizens in decisionmaking — would be difficult to achieve.

Today, Church is a bigger fan of health regions than he was in the 1990s. As they evolved, health regions succeeded in creating some of the benefits that advocates of regionalization had suggested would occur, he says. Alberta had particularly strong regional health authorities and was viewed by many as a poster boy for regionalization.

Still, there are benefits to having a single board, suggests Church. A single entity can save more money when bulk purchasing medical equipment, drugs and computers. And the government no longer has to referee squabbles between health regions, which could save the province both time and money.

Then again, the government may have abolished health regions simply for political reasons and not for economic benefit or to improve efficiency.

"The health regions had developed a strong voice, and that voice became a growing challenge to what the government wanted to do," says Church. "The way to get rid of that voice is to get rid of health regions." - Roger Collier, CMAJ

DOI:10.1503/cmaj.109-3165 